\title{
Peopling, demographic history and genetic structure of the Azores Islands: Integrating data from mtDNA and Y-chromosome
}

\author{
Cristina Santos ${ }^{\mathrm{a}, *}$, Rafael Montiel ${ }^{\mathrm{a}}$, Conceição Bettencourt ${ }^{\mathrm{a}}$, \\ M. João Prata ${ }^{b}$, Augusto Abade ${ }^{c}$, M. Pilar Aluja ${ }^{\mathrm{d}}$, Manuela Lima ${ }^{\mathrm{a}}$ \\ ${ }^{\text {a } C I R N ~ a n d ~ D e p a r t m e n t ~ o f ~ B i o l o g y, ~ U n i v e r s i t y ~ o f ~ t h e ~ A z o r e s, ~ P o r t u g a l ~}$ \\ ${ }^{\mathrm{b}}$ Institute of Molecular Pathology and Immunology of the University of Porto, Portugal \\ ${ }^{c}$ Department of Anthropology, University of Coimbra, Portugal \\ ${ }^{\mathrm{d}}$ Department of BAVE, University Autonóma of Barcelona, Spain
}

\begin{abstract}
We have conducted studies to assess the variability of mtDNA and Y-chromosome markers in the Azores Islands (Portugal) and found that, for both genetic systems, the Azores, as a whole, fit well into the pattern of variation described for other Western European populations. Phylogeographic analysis of mitochondrial DNA (mtDNA) showed a major contribution from Mainland Portugal, as well as evidences of influxes from Northern Europeans, Africans and Jewish groups. Characterization of markers on the non-recombining region of the Y-chromosome (NRY) has shown a main component of European lineages as well as the presence of North African chromosomes, in frequencies similar to those described for Mainland Portugal. On the other hand, both mtDNA and NRY analyses have evidenced differential demographic histories for the three groups of islands forming the archipelago. (C) 2005 Elsevier B.V. All rights reserved.
\end{abstract}

Keywords: Azores Islands (Portugal); mtDNA; NRY; Population structure; Demographic history

\section{Introduction}

The Azores Islands were discovered uninhabited by Portuguese navigators in the early 15 th century. The process of settlement was initiated by 1439 , with main imports coming from Mainland Portugal and Madeira Island [1]. Immigrants from other European regions, African and Moorish slaves as well as Sephardic Jews, are also reported [1].

\footnotetext{
* Corresponding author. Tel.: +351 296650118; fax: +351 296650100.

E-mail address: cristinasantos@notes.uac.pt (C. Santos).
} 
In the present work, we compare the mtDNA (mtDNA) ([2] and present study) and NRY [3] haplogroup composition of the three groups of Azorean Islands.

\section{Materials and methods}

mtDNA haplogroups were determined for 26 unrelated individuals born in Santa Maria Island (Eastern group), following Santos et al. [2]. Additional mtDNA data were extracted from Santos et al. [2]. Data on NRY were obtained from Montiel et al. [3].

\section{Results and discussion}

On what concerns mtDNA, in the total sample, all West-Eurasian haplogroups were found (Table 1). The African clusters U6a, M1, L1, L2 and L3, as well as the Near-East N1b cluster, were also identified. These results evidence a mixed composition of mtDNAs in the Azores Islands, which is in accordance with historical data [1]. The comparison of the mtDNA haplogroup distribution among the three groups of islands revealed differences only when the Western group is compared with the other two (Western/Eastern: $p<0.0001$; Western/Central: $p=0.0004)$.

The NRY haplogroup distribution in the Azores is similar to the observed in other WestEuropean populations (Table 1). The most frequent haplogroups were R1(xR1b3f), E(xE3a) and J. Again, the Western group appears to be the most differentiated, showing significant differences when compared with the other two groups (Western/Eastern: $p=0.008$; Western/ Central: $p=0.025$ ). The two systems show values of Nei's diversity [4] relatively high, in the context of other West-European populations (Table 2). Values of mtDNA diversity (calculated using either the distribution of haplogroups or haplotypes) do not present statistically significant differences in the three groups of islands. An increase in NRY diversity values from East towards West is observed. Furthermore, the diversity level in the Western group is

Table 1

Haplogroup frequencies of mtDNA and NRY observed in the total Azorean samples, as well as the partial frequencies observed in the Eastern, Central and Western groups

\begin{tabular}{|c|c|c|c|c|c|c|c|c|c|}
\hline $\begin{array}{l}\text { mtDNA } \\
\text { haplogr. }\end{array}$ & $\begin{array}{l}\text { Azores } \\
(n=172)\end{array}$ & $\begin{array}{l}\text { Eastern } \\
(n=76)\end{array}$ & $\begin{array}{l}\text { Central } \\
(n=60)\end{array}$ & $\begin{array}{l}\text { Western } \\
(n=36)\end{array}$ & $\begin{array}{l}\text { NRY } \\
\text { haplogr. }\end{array}$ & $\begin{array}{l}\text { Azores } \\
(n=185)\end{array}$ & $\begin{array}{l}\text { Eastern } \\
(n=87)\end{array}$ & $\begin{array}{l}\text { Central } \\
(n=76)\end{array}$ & $\begin{array}{l}\text { Western } \\
(n=22)\end{array}$ \\
\hline $\mathrm{H}$ & 36.05 & 39.47 & 40.00 & 22.22 & $\mathrm{C}$ & 1.60 & 4.55 & 0.00 & 2.30 \\
\hline I & 1.74 & 0.00 & 5.00 & 0.00 & $\mathrm{E}(\mathrm{xE} 3 \mathrm{a})$ & 11.23 & 18.18 & 8.97 & 11.49 \\
\hline $\mathrm{J}$ & 9.88 & 11.84 & 13.33 & 0.00 & $\mathrm{~F}(\mathrm{xJ}, \mathrm{K})$ & 3.74 & 4.55 & 7.69 & 0.00 \\
\hline L1, L2, L3 & 2.33 & 3.95 & 1.67 & 0.00 & G & 3.21 & 9.09 & 1.28 & 3.45 \\
\hline M1 & 2.33 & 1.32 & 1.67 & 5.56 & I & 1.07 & 0.00 & 2.56 & 0.00 \\
\hline N1b & 1.16 & 1.32 & 1.67 & 0.00 & $\mathrm{I}(\mathrm{xI} 1 \mathrm{~b} 2)$ & 3.21 & 4.55 & 5.13 & 1.15 \\
\hline $\mathrm{T}$ & 12.79 & 7.89 & 15.00 & 19.44 & $\mathrm{I} 1 \mathrm{~b} 2$ & 4.28 & 13.64 & 2.56 & 3.45 \\
\hline $\mathrm{U}$ & 6.98 & 13.16 & 1.67 & 2.78 & $\mathrm{~J}$ & 8.02 & 9.09 & 12.82 & 3.45 \\
\hline U6a & 1.74 & 3.95 & 0.00 & 0.00 & $\mathrm{~K}(\mathrm{xL}, \mathrm{N}, \mathrm{O}, \mathrm{P})$ & 1.60 & 0.00 & 2.56 & 1.15 \\
\hline $\mathrm{U} 6 \mathrm{~b}$ & 2.91 & 3.95 & 0.00 & 5.56 & $\mathrm{~L}$ & 1.07 & 0.00 & 0.00 & 2.30 \\
\hline K & 5.81 & 6.58 & 6.67 & 2.78 & $\mathrm{~N}$ & 1.07 & 0.00 & 0.00 & 2.30 \\
\hline Pre-HV & 0.58 & 0.00 & 1.67 & 0.00 & $\mathrm{O}$ & 0.53 & 0.00 & 1.28 & 0.00 \\
\hline Pre*V & 1.74 & 1.32 & 0.00 & 5.56 & $\mathrm{P}(\mathrm{xR})$ & 0.53 & 4.55 & 0.00 & 0.00 \\
\hline $\mathrm{V}$ & 9.30 & 2.63 & 3.33 & 33.33 & $\mathrm{R}$ & 1.60 & 0.00 & 3.85 & 0.00 \\
\hline W & 1.74 & 1.32 & 3.33 & 0.00 & $\mathrm{R} 1$ & 0.53 & 0.00 & 1.28 & 0.00 \\
\hline $\mathrm{X}$ & 2.33 & 1.32 & 3.33 & 2.78 & R1(xR1b3f) & 54.55 & 27.27 & 47.44 & 67.82 \\
\hline $\mathrm{R}^{*}$ & 0.58 & 0.00 & 1.67 & 0.00 & R1b3f & 2.14 & 4.55 & 2.56 & 1.15 \\
\hline
\end{tabular}


Table 2

Nei's gene diversity and its standard error [4], estimated from mtDNA and NRY data for the total Azorean sample and by groups of islands

\begin{tabular}{llll}
\hline Population & mtDNA (haplogroups) & mtDNA (haplotypes) & NRY \\
\hline Azores & $0.828 \pm 0.022$ & $0.959 \pm 0.010$ & $0.627 \pm 0.038$ \\
Eastern group & $0.807 \pm 0.037$ & $0.948 \pm 0.018$ & $0.522 \pm 0.061$ \\
Central group & $0.801 \pm 0.042$ & $0.956 \pm 0.019$ & $0.650 \pm 0.057$ \\
Western group & $0.813 \pm 0.039$ & $0.917 \pm 0.028$ & $0.857 \pm 0.047$ \\
\hline
\end{tabular}

significantly different from that observed in the Central $(p=0.0063)$ or in the Eastern $(p<0.0001)$ groups.

\section{Conclusions}

The high level of diversity observed in mtDNA and NRY can be explained by the recent and highly diverse origins of the Azorean population. For both systems analyzed, the Western group resulted to be differentiated from the other two groups. On what concerns mtDNA, this differentiation does not seem to stem from a differential settlement, but can be a reflection of genetic drift increased by the reduced number of inhabitants since peopling. On the other hand, differences in NRY can be explained by a differential male composition during the settlement, contrarily to the similar female compositions that have been deduced from mtDNA data. As the number of male and female African slaves arriving to the Western group has been estimated as similar (Lima, personal communication) its differential Y-chromosome composition probably results from the low number of European male settlers, as evidenced by the low frequency of haplogroup $\mathrm{R} 1$ and high frequencies of $\mathrm{E}(\mathrm{xE} 3 \mathrm{a})$. First demographic information by sex, available for the Azores, dated from 1776 [5], reveals that the sex ratio increases from East towards West, similarly to the levels of NRY diversity. Considering globally, results obtained reinforce the absolute need to integrate demographic and historical data in the interpretation of genetic results.

\section{Acknowledgments}

CIRN; FCT (SFRH/BPD/13256/2003 to RM and SFRH/BPD/20944/2004 to CS); the participation of CS and ML in the ISFG meeting was financed by Direcção Regional da Ciência e Tecnologia (Regional Government of the Azores).

\section{References}

[1] L. Mendonça, História dos Açores-Visão geral (sécs. XV-XIX), Centro de Apoio Tecnológico à Educação, Ponta Delgada, Azores, 1996.

[2] C. Santos, et al., Genetic structure and origins of peopling in the Azores Islands (Portugal): the view from mtDNA, Ann. Hum. Genet. 67 (2003) 433-456.

[3] R. Montiel, et al., Analysis of Y-chromosome variability and its comparison with mtDNA variability reveals different demographic histories between islands in the Azores archipelago (Portugal), Ann. Hum. Genet. 69 (2005) $1-10$

[4] M. Nei, Molecular Evolutionary Genetics, Columbia University Press, New York, 1987.

[5] A. Madeira, População e Emigração nos Açores (1766-1820), Patrimonia, Cascais, Portugal, 1999. 